\title{
Pengaruh Model Pembelajaran Problem Based Learning (PBL) Berbantukan LKS terhadap Aktifitas dan Hasil Belajar Siswa Kelas XI MIA MAN-1 Pekanbaru Tahun Pelajaran 2016-2017
}

\author{
Istiqomah \\ Guru MAN-1 Pekanbaru \\ Email: istiqomah7827@grad.unri.ac.id
}

\begin{tabular}{l}
\hline INFO ARTIKEL \\
\hline Riwayat Artikel: \\
Diterima: 13-12-2019 \\
Disetujui: $16-12-2019$
\end{tabular}

\section{Kata kunci:}

Problem based learning (PBL)

Hasil Belajar

Aktifitas Belajar

\author{
Alamat Korespondensi: \\ Istiqomah \\ Guru MAN-1 Pekanbaru \\ E-mail: istiqomah7827@grad.unri.ac.id

\begin{abstract}
ABSTRAK
Abstract: This study aims to see an increase in the activities and learning outcomes of class XI MIA students in biology. This type of research is a Quasi Experiment research. Classes that are sampled are class XI MIA 2 as Experiment class and class XI MIA 3 as control class. The study was conducted in August until December 2016. The parameters measured were learning outcomes and student learning activities. The experimental design used in this study took the form of a $2 \times 2$ factorial design, with the independent variable Problem Based Learning model assisted by LKS and conventional learning models. While the dependent variable is learning outcomes and learning activities. The results show that student learning outcomes in the experimental class increased from $\mathrm{kd} 1$ to the second KD. In KD 1 the categories of learning outcomes are high, medium and low, respectively $27.77 \%, 55.55 \%$ and $16.61 \%$. And in the second KD equal to $22.22 \%, 69.44 \%$ and $8.33 \%$. While in the control class in the first, high, medium and low categories were $19.44 \%, 63.88 \%$ and $16.61 \%$. And the second KD was $13.88 \%, 69.44 \%$ and $16.66 \%$. Student learning activities in the experimental class has 67,58 is high more than convensional class with score 57,41 .

Abstrak: Penelitian ini bertujuan untuk melihat peningkatan aktifitas dan hasil belajar siswa kelas XI MIA pada pelajaran biologi. Jenis penelitian yang dilakukan adalah penelitian Quasi Eksperimen. Kelas yang dijadikan sampel adalah kelas XI MIA 2 sebagai kelas Eksperimen dan kelas XI MIA 3 sebagai kelas kontrol. Penelitian dilakukan bulan agustus hingga desember 2016. Parameter yang diukur adalah hasil belajar dan aktifitas belajar siswa. Design eksperimen yang digunakan dalam penelitian ini berbentuk design factorial 2x2, dengan variable bebas model Problem Based Learning berbantukan LKS dan model pembelajaran konvensional. Sedangkan variable terikatnya adalah hasil belajar dan aktifitas belajar. Hasil menunjukkan bahwa hasil belajar siswa pada kelas eksperimen meningkat dari kd 1 ke KD kedua. Pada KD 1 kategori hasil belajar kategori tinggi, sedang dan rendah masing-masing 27,77\%, 55,55 \% dan 16,61\%. Dan pada KD ke 2 sebesar $22,22 \%, 69,44 \%$ dan 8,33\%. Sementara pada kelas control pada kd 1 kategori tinggi, sedang dan rendah adalah sebesar 19,44 \%, 63,88\% dan 16,61 \%. Dan pada KD kedua sebesar 13,88\%, 69,44\% dan 16,66\%. Aktifitas belajar siswa yang diajar dengan pembelajaran PBL sebesar 67, 58 lebih baik dibandingkan dengan aktifitas belajar siswa dengan pola konvensional yakni sebesar 57,41
\end{abstract}

\section{LATAR BELAKANG}

Pendidikan merupakan kegiatan untuk membantu perkembangan peserta didik mencapai tujuan-tujuan pendidikan. Kegiatan pendidikan berintikan interaksi antara peserta didik dengan pendidik dan sumber-sumber pendidikan lain, dan berlangsung dalam suatu lingkungan pendidikan. Kegiatan pendidikan berfungsi membantu mengembangkan potensi, kecakapan dan karakteristik peserta didik agar berkembang sesuai harapan masyarakat. Interaksi pendidikan dapat berbentuk aktifitas pendidik dalam mendidik dan membelajarkan peserta didik yang berlangsung dalam suatu institusi pendidikan. (Sukmadinata, 2007). Pembelajaran atau pengajaran pada dasarnya merupakan kegiatan menciptakan situasi agar siswa belajar. Mengajar dan belajar merupakan kegiatan yang tidak dapat dipisahkan. Melalui proses belajar tersebut 
terjadi perubahan, perkembangan, kemajuan, baik dalam aspek fisik motorik, intelektual, sosial emosional maupun sikap dan nilai. Makin besar perkembangan yang dicapai oleh siswa maka semakin baiklah proses belajar (Syaodih Nana, 2007) .

Sesuai dengan tuntutan kurikulum 13, ada tiga capaian yang hendak diwujudkan dalam proses pembelajaran sesuai kurikulum ini, yakni kompetensi, karakter dan kemampuan literasi. Capaian kompetensinya adalah mencakup bagaimana peserta didik dapat menghadapi tantangan yang kompleks, menghadapi lingkungan yang terus berubah melalui penguatan karakter dan bagaimana menerapkan kemampuan inti dalam kegiatan sehar-hari melalui ketrampilan literasi. Untuk memenuhi tuntutan kurikulum tersebut maka dalam proses pembelajaran perlu digunakan pendekatan dan model pembelajaran yang tepat. Pemilihan pendekatan, dan model mengajar, hendaknya didasarkan berbagai pertimbangan diantaranya tujuan pembelajaran, karakteristik mata pelajaran, kemampuan siswa, motivasi belajar siswa dan kemampuan guru. Namun kenyataannya yang terjadi dilapangan model pembelajaran masih menggunakan cara konvensional sehingga hasil dari proses pembelajaran sering tidak sesuai dengan yang diharapkan.

MAN -1 Pekanbaru sebagai salah satu Madrasah Aliyah Negeri di Pekanbaru, juga masih banyak ditemukan hasil pembelajaran yang tidak sesuai dengan harapan. Ada beberapa penyebabnya, yakni dari aspek siswa sebagai peserta didik, media ajar yang digunakan guru belum bervariasi dan strategi pembelajaran yang digunakan belum memenuhi kriteria maksimal yang diharapkan kurikulum. Ditinjau dari aspek belajar siswa, penyebab rendahnya hasil belajar adalah kemauan belajar siswa yang masih rendah. Pada saat proses belajar masih ada siswa yang mengobrol dengan teman lainnya, tidak fokus dan ada yang mengerjakan tugas lain. Persentase siswa yang bertanya juga masih rendah. Hal ini menunjukkan kemampuan siswa untuk mengungkapkan gagasan, berpikir kritis dan penyelesaian masalah masih rendah. Jika ditinjau dari aspek model pembelajaran, masih banyak guru yang menggunakan model pembelajaran tidak sesuai dengan tuntutan yang tercantum dalam Kurikulum-13. Sementara dari segi penggunaan media, banyak media yang dipakai masih sederhana. Salah satu media yang sering digunakan guru adalah LKS (Lembar kerja Siswa). LKS yang digunakan adalah LKS yang beredar di pasaran yang isinya belum tentu sesuai dengan kompetensi dasar (KD) dan indikator pembelajaran. Banyak LKS yang digunakan tersebut belum memuat konten-konten penting seperti penemuan atau pemecahan masalah. Tampilan LKS juga sering tidak menarik sehingga tidak dapat meningkatkan hasil belajar siswa.

Berangkat dari permasalahan masih rendahnya hasil belajar maka perlu dirancang kegiatan pembelajaran yang dapat meningkatkan hasil belajar dan aktifitas siswa. Sekolah harus mampu memberikan pengalaman belajar kepada siswa dan memberikan motivasi yang positif, dalam diri siswa prestasi yang dicapai juga meningkat. Salah satu cara untuk mendapatkan hasil belajar dan aktifitas belajar adalah dengan menggunakan model, strategi, dan media pembelajaran yang tepat, yang disesuaikan dengan kompetensi dasar yang ingin dicapai dalam kurikulum. Menurut (Sumiati\& Asra, 2007) strategi pembelajaran merupakan cara-cara yang akan dipilih atau digunakan oleh seorang guru untuk menyampaikan materi pembelajaran sehingga akan memudahkan siswa menerima dan memahami materi pembelajaran yang pada akhirnya tujuan belajar akan tercapai.

Salah satu model yang dapat digunakan adalah pemecahan masalah (Problem Based Learning/PBL). Pemilihan model PBL sesuai dengan karakteristik mata pelajaran Biologi yang dikembangkan melalui kemampuan berpikir analisis, induktif, deduktif dan pemecahan masalah yang berkaitan dengan alam sekitar. PBL merupakan pembelajaran dimana masalah yang menggendalikan pembelajaran, artinya pembelajaran dimulai dengan menyajikan masalah konstektual yang harus dipecahkan dan masalah dimunculkan sedemikian rupa sehingga siswa memperoleh pengetahuan baru sebelum mereka dapat memecahkan masalah. Jadi, siswa harus menginterpretasikan masalah, menggumpulkan informasi, mengevaluasi alternatif pemecahan masalah dan mempresentasikan solusinya. Masalah pada hakekatnya merupakan sebuah pertanyaan yang mengundang jawaban. Siswa hendaknya dirangsang dan didorong mengenal, merumuskan dan memecahkan masalah sesuai dengan kemampuannya. Rusman (2013) menyebutkan bahwa Problem Based Learning merupakan inovasi dalam pembelajaran karena dalam PBL kemampuan berfikir siswa betul-betul dioptimalisasikan melalui proses kerja kelompok atau tim yang sistematis, sehingga siswa dapat memberdayakan, mengasah, menguji dan mengembangkan kemampuan berfikir siswa secara berkesinambungan. Model PBL memiliki keunggulan dapat merangsang daya analisis siswa dalam menghadapi suatu masalah dan mencari pemecahannya (Chin Pei Tan et al, 2016). Riset yang dilakukan oleh Elaine et al (2016) menunjukkan bahwa terjadi peningkatan kemampuan dalam belajar dengan menggunakan PBL yang dikemas dalam bentuk pertanyaan yang bervariasi.

Untuk meningkatkan aktifitas dan hasil belajar siswa kelas XI Man-1 Pekanbaru tahun ajaran 2016-2017 tersebut maka peneliti ingin melihat bagaimanakah pengaruh model pembelajaran Problem Based Learning berbantukan LKS dalam meningkatkan aktifitas dan hasil belajar siswa kelas XI MIA MAN-1 Pekanbaru. Maka tujuan dari penelitian ini adalah : 1). Melihat Perbedaan aktifitas belajar siswa kelas X Man-1 Pekanbaru yang diajar dengan model pembelajaran Problem Based Learning berbantukan LKS Dengan kelas yang diajar menggunakan metode konvensional. 2). Melihat Perbedaan hasil belajar siswa kelas X Man-1 Pekanbaru yang diajar dengan model pembelajaran Problem Based Learning berbantukan LKS Dengan kelas yang diajar menggunakan metode konvensional. Manfaat yang diharapkan dari penelitian ini adalah : 1). Bagi peserta didik diharapkan lebih termotivasi dan mendapatkan hasil belajar memuaskan, 2).Bagi pendidik dapat dijadikan salah satu pendekatan alternative agar pembelajaran biologi lebih variatif dan bermakna sehingga dapat meningkatkan hasil belajar dan aktifitas belajar yang baik. 3). Bagi Sekolah, diharapkan dapat menjadi masukan dalam rangka meningkatkan mutu pembelajaran dan 4). Bagi dunia penelitian, dapat dijadikan sumber informasi dan referensi untuk penelitian selanjutnya. 


\section{METODE}

Jenis penelitian ini adalah penelitian Quasi eksperimen, dimana variable penelitian tidak mungkin dikontrol secara penuh. Kelas- kelas yang ada, dipakai untuk melakukan penelitian sehingga tidak dibuat kelas baru. Penelitian ini dilaksanakan pada semester 1 (ganjil) Tahun pelajaran 2016-2017, di MAN 1 Pekanbaru. Populasi penelitian ini adalah seluruh siswa kelas XI MAN-1 PEKANBARU tahun ajaran 2016-2017 yang terdiri dari 5 kelas. Sampel dalam penelitian ini terdiri dari dua kelas yakni kelas XI MIA 3 sebagai kelas control dan XI MIA 2 sebagai kelas eksperimen. Pelaksanaan penelitian ini meliputi pembelajaran menggunakan model Problem Based Learning berbantukan LKS dan model pembelajaran konvensional. Design eksperimen yang digunakan dalam penelitian ini berbentuk design factorial $2 \times 2$, dengan variable bebas model Problem Based Learning berbantukan LKS dan model pembelajaran konvensional. Sedangkan variable terikatnya adalah hasil belajar dan aktifitas belajar. Rancangan penelitian disajikan pada Tabel 1 .

\section{Tabel 1. Desain Penelitian}

\begin{tabular}{lll}
\hline \multirow{2}{*}{ Model } & \multicolumn{2}{c}{ Setting Penelitian } \\
\cline { 2 - 3 } & Hasil belajar (B1) & Motivasi Belajar (B2) \\
\hline PBL berbantukan LKS (A1) & A1B1 & A1B2 \\
Konvensional (A2) & A2B1 & A2B2 \\
\hline
\end{tabular}

Keterangan:

$\mathrm{A}_{1} \mathrm{~B}_{1}$ : Hasil belajar siswa dalam mata pelajaran biologi yang diajar dengan model PBL berbantukan LKS

$\mathrm{A}_{2} \mathrm{~B}_{1}$ : Hasil belajar siswa dalam mata pelajaran biologi yang diajar dengan model konvensional

A1B2 : Aktifitas belajar siswa yang diajar dengan model PBL berbantukan LKS

A2B2 : Aktifitas Belajar siswa yang diajar dengan model konvensional

Instrumen pengumpul data terdiri dari 1). Soal UH untuk mendapatkan hasil belajar dan 2). Angket aktifitas belajar siswa. Tehnik pengumpulan data, Untuk mengukur pengetahuan siswa terhadap materi yang diberikan, baik dengan menggunakan model PBL maupun menggunakan model konvensional maka dilakukan tes. Tes yang diberikan berbentuk pilihan ganda. Penskoran tes menggunakan rumus Arikunto (2013) yaitu:

\section{$\mathrm{S}=\mathrm{JB} / \mathrm{JS} \mathrm{X} 100$}

Keterangan:

S : Skor

JB : Jumlah betul

JS : Jumlah soal

Data aktivitas siswa didalam penelitian ini dianalisis secara kualitatif dan kuantitatif dengan instrumen adalah lembar observasi, catatan lapangan yang dibantu oleh 1 orang guru/observer dengan menggunakan format yang sudah disiapkan sehingga observer memberi tanda ceklist pada lembar tersebut. Sementara itu, teknik analisa data digunakan, data hasil pengisian lembaran aktivitas siswa dianalisis dengan rumus berikut:

$$
\text { Persentase }=\frac{\text { Jumlah skor yang diperoleh siswa }}{\text { Skor maksimal }} x 100 \%
$$

Untuk mengetahui tingkat aktivitas belajar siswa, Dimyati dan Mudjiono (1999) memberikan kriteria disajikan pada Tabel 2, sebagai berikut:

Tabel 2. Kriteria Aktifitas Belajar Siswa

\begin{tabular}{cc}
\hline Range skor & Kriteria Aktivitas Siswa \\
\hline $76-100$ & Sangat tinggi \\
$51-75$ & Tinggi \\
$26-50$ & Rendah \\
$1-25$ & Sangat rendah \\
\hline
\end{tabular}

Sementara itu, Data penelitian ini dianalisis dengan menggunakan analisis rata-rata. Adapun langkah-langkah dalam analisis data ini meliputi: membuat deskripsi data, melakukan pengujian prasyarat analisis, dan melakukan pengujian hipotesis penelitian. Deskripsi data ini menyajikan keadaan data masing-masing kelompok data penelitian, seperti skor tertinggi, skor terendah, jarak pengukuran (range), rerata skor (mean). Untuk menguji hipotesis digunakan statistik uji perbedaan dengan menggunakan uji-t untuk hasil belajar. Rumus uji-t yang dikemukakan oleh Sugiyono (2013), yaitu:

Untuk $n$ sama digunakan rumus:

Keterangan :

$$
\mathrm{t}=\frac{\bar{x}_{1}-\bar{x}_{2}}{\sqrt{\frac{s_{1}^{2}}{n_{1}}+\frac{s_{2}^{2}}{n_{2}}}}
$$

$\bar{X}_{1} \quad$ : rata-rata nilai kelompok eksperimen

$\bar{X}_{2}^{1} \quad$ : rata-rata nilai kelompok kontrol

$n_{1}$ : responden kelas eksperimen

$n_{2} \quad$ : responden kelas kontrol

$S \quad$ : simpangan baku 


\section{HASIL DAN PEMBAHASAN}

\section{Hasil Belajar Siswa dalam Mata Pelajaran yang Diajar dengan PBL}

Pada KD system Gerak Dari hasil pengukuran sampel dalam kelompok ini skor tertinggi 88, skor terendah 46, jarak pengukuran (range) 42, rerata skor 66,06. Nilai skor yang didapat kemudian di kelompokkan kedalam kategori pencapaian pengetahuan yang diadaptasi dari Campbell (1999) yang membagi kedalam 4 kategori pengetahuan yaitu kategori tinggi (76100), sedang (51-75), rendah (26-50) dan kategori sangat rendah (0-25). Hasil analisis capaian siswa didapatkan kategori capaian siswa pada kelas exsperimen disajikan pada Tabel 3.

Tabel 3. Capaian Pengetahuan Siswa Pada Kelas Eksperimen Pada KD System Gerak

\begin{tabular}{clcc}
\hline No & Kategori & Jumlah siswa & Persentase \\
\hline 1 & Tinggi & 10 & 27,77 \\
2 & Sedang & 20 & 55,55 \\
3 & Rendah & 6 & 16,66 \\
4 & Sangat rendah & - & \\
\hline \multicolumn{2}{c}{ Total } & 36 & 100 \\
\hline
\end{tabular}

Pada Tabel 3 dapat dijelaskan bahwa terdapat 10 siswa yang memiliki pengetahuan kategori tinggi, 20 orang kategori sedang dan terdapat 6 orang kategori rendah, sementara tidak terdapat siswa dengan kategori pengetahuan sangat rendah. Untuk nilai tertinggi didapatkan skor 88 dengan jumlah anak sebanyak 2 orang. Sedangkan nilai terendah yakni 46 didapat oleh satu orang peserta.

Sementara itu untuk tes ulangan harian KD system peredaran darah didapatkan Dari hasil pengukuran sampel dalam kelompok ini skor tertinggi 94, skor terendah 42, jarak pengukuran (range) 52, rerata skor 68,02. Nilai skor yang didapat kemudian juga di kelompokkan kedalam kategori pencapaian pengetahuan. Hasil analisis capaian siswa kelas exsperimen pada KD system peredaran darah disajikan pada Tabel 4.

Tabel 4. Capaian Pengetahuan Siswa Pada Kelas Eksperimen Pada KD Sistem Peredaran Darah

\begin{tabular}{clcc}
\hline No & Kategori & Jumlah siswa & Persentase \\
\hline 1 & Tinggi & 8 & $22,22 \%$ \\
2 & Sedang & 25 & $69,44 \%$ \\
3 & Rendah & 3 & $8,33 \%$ \\
4 & Sangat rendah & - & \\
\hline \multicolumn{2}{c}{ Total } & 36 & 100 \\
\hline
\end{tabular}

Pada tabel 4, dapat dijelaskan bahwa terdapat 8 atau sebanyak 22,22\% siswa yang memiliki pengetahuan kategori tinggi, 25 atau $69,44 \%$ orang kategori sedang dan terdapat 3 atau 8,33\% orang kategori rendah, sementara tidak terdapat siswa dengan kategori pengetahuan sangat rendah. Untuk nilai tertinggi didapatkan skor 94 dengan jumlah anak sebanyak 1 orang. Sedangkan nilai terendah yakni 42 didapat oleh satu orang peserta.

Dari hasil perolehan capaian pada KD gerak ke KD system peredaran darah terlihat terdapat sedikit peningkatan dalam capaian skor pengetahuan. Peserta didik banyak memiliki kategori pada pengetahuan sedang. Walaupun hanya terjadi sedikit kenaikan namun capaian tertinggi nilai tes $(\mathrm{UH})$ meningkat cukup baik yakni dari skor 88 ke skor 94 . Grafik perbandingan capaian skor siswa pada pengetahuan lingkungan pada $2 \mathrm{KD}$ yang di perlakukan disajikan pada gambar 1 .

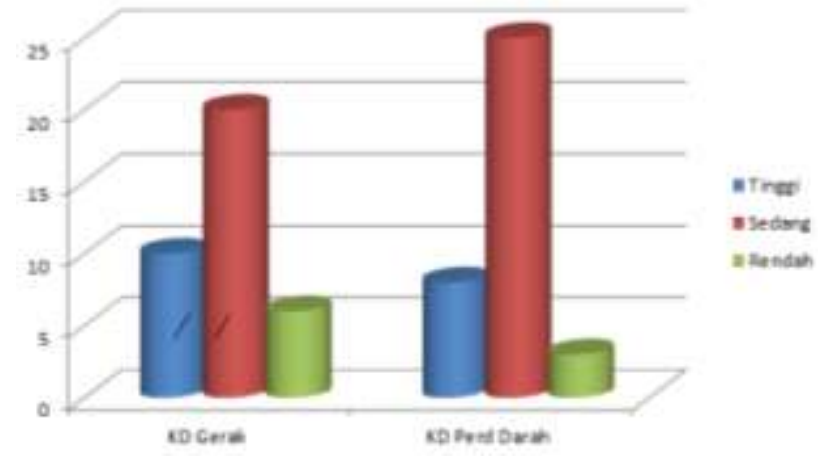

Gambar 1. Perbandingan Capaian Skor Pengetahuan Pada 2 KD di Kelas Eksperimen

Dari gambar grafik 1 terlihat bahwa capaian kategori tinggi meningkat pada KD ke 2 (Sistem peredaran darah) dan Terjadi penurunan pada kategori rendah dan kategori tinggi.

Hasil Belajar Siswa dalam Mata Pelajaran yang Diajar dengan metode konvensional (Ceramah)

Pada KD system Gerak Dari hasil pengukuran sampel dalam kelompok kelas control yang melaksanakan pembelajaran dengan metode konvensional didapat skor tertinggi 86, skor terendah 32, jarak pengukuran (range) 54, rerata skor 62,74. Nilai skor yang didapat kemudian di kelompokkan kedalam kategori pencapaian pengetahuan kedalam 4 kategori 
80 Instructional Development Journal (IDJ), Vol. 2, No. 2, Desember 2019, Hal. 76-85

pengetahuan yaitu kategori tinggi (76-100), sedang (51-75), rendah (26-50) dan kategori sangat rendah (0-25). Hasil analisis capaian siswa pada KD system gerak pada kelas control disajikan pada Tabel 5.

Tabel 5. Capaian Pengetahuan Siswa Pada Kelas Control Pada KD System Gerak

\begin{tabular}{clcc}
\hline No & Kategori & Jumlah siswa & Persentase \\
\hline 1 & Tinggi & 7 & 19,44 \\
2 & Sedang & 23 & 63,88 \\
3 & Rendah & 6 & 16,66 \\
4 & Sangat rendah & - & - \\
\hline & Total & 36 & 100 \\
\hline
\end{tabular}

Pada tabel 5, dapat dijelaskan bahwa terdapat 7 atau sebesar 19,44\% siswa yang memiliki pengetahuan kategori tinggi, 23 atau 63,88\% orang kategori sedang dan terdapat 6 atau 16,66 orang kategori rendah, sementara tidak terdapat siswa dengan kategori pengetahuan sangat rendah. Untuk nilai tertinggi didapatkan skor 86 dengan jumlah anak sebanyak 1 orang. Sedangkan nilai terendah yakni 32 didapat oleh satu orang peserta.

Sementara itu untuk tes ulangan harian KD system peredaran darah didapatkan Dari hasil pengukuran sampel dalam kelompok ini skor tertinggi 89, skor terendah 42, jarak pengukuran (range) 47, rerata skor 79. Nilai skor yang didapat kemudian juga di kelompokkan kedalam kategori pencapaian pengetahuan. Hasil analisis capaian siswa kelas exsperimen pada KD system peredaran darah disajikan pada Tabel 6.

Tabel 6. Capaian Pengetahuan Siswa Pada Kelas Eksperimen Pada KD Sistem Peredaran Darah

\begin{tabular}{clcc}
\hline No & Kategori & Jumlah siswa & Persentase \\
\hline 1 & Tinggi & 5 & 13,88 \\
2 & Sedang & 25 & 69,44 \\
3 & Rendah & 6 & 16,66 \\
4 & Sangat rendah & - & - \\
\hline & Total & 36 & 100 \\
\hline
\end{tabular}

Pada tabel 6, dapat dijelaskan bahwa terdapat 5 atau sebanyak 13,88\% siswa yang memiliki pengetahuan kategori tinggi, 25 atau 69,44\% orang kategori sedang dan terdapat 6 atau 16,6 \% orang kategori rendah, sementara tidak terdapat siswa dengan kategori pengetahuan sangat rendah. Untuk nilai tertinggi didapatkan skor 8 dengan jumlah anak sebanyak 1 orang. Sedangkan nilai terendah yakni 45 didapat oleh satu orang peserta.

Dari hasil perolehan capaian pada KD gerak ke KD system peredaran darah di kelas control terlihat bahwa terdapat sedikit peningkatan dalam capaian skor pengetahuan. Peserta didik banyak memiliki kategori pada pengetahuan sedang sementara untuk kategori tinggi dan rendah relative sama. Gambar 2, akan menyajikan Grafik perbandingan capaian skor siswa pada pengetahuan lingkungan pada $2 \mathrm{KD}$ dikelas control.

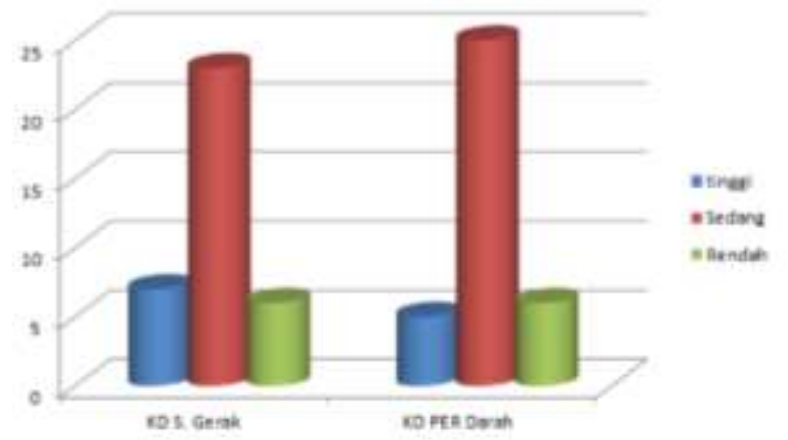

Gambar 2. Perbandingan Capaian Skor Pengetahuan Pada 2 KD Kelas Kontrol

Dari gambar 2, terlihat bahwa secara umum capaian KD berada pada kategori sedang sementara itu capaian kategori tinggi dan kategori rendah relative sama pada kedua KD.

Berdasarkan hasil penelitian, dapat terlihat bahwa penerapan model pembelajaran kooperatif tipe PBL dapat meningkatkan hasil belajar siswa dalam mata pelajaran biologi. Gambaran di atas sejalan dengan hasil pengamatan yang peneliti amati selama pembelajaran, bahwa siswa pada kelas eksperimen mempunyai semangat lebih tinggi dalam memperhatikan dan merespon penjelasan guru dibandingkan dengan siswa kelas kontrol. Hal ini mengindikasikan bahwa siswa pada kelas eksperimen cukup paham dengan materi yang disajikan. Dalam mengerjakan LKS siswa terlihat sangat antusias untuk menjawab pertanyaan yang ada. Hal ini sangat berbeda dengan kegiatan yang dilakukan oleh kelompok kelas kontrol yang hanya mengerjakan soal-soal latihan yang jawabannya ada di buku paket.

Hasil belajar siswa dalam mata pelajaran biologi kelompok yang diajar dengan menggunakan model pembelajaran kooperatif tipe PBL lebih tinggi secara signifikan dari hasil belajar siswa yang diajar dengan model pembelajaran konvensional. Hal ini disebabkan karena pada penggunaan model pembelajaran kooperatif tipe PBL dapat memberikan motivasi bagi siswa dalam menjawab soal-soal. Bukti ini memperlihatkan bahwa siswa lebih bersemangat dalam belajar dan 
lebih berpartisipasi dalam proses pembelajaran. Dalam mengikuti setiap aktivitas pembelajaran, siswa berusaha memahami materi pelajaran dengan cara bertanya kepada teman, bertanya pada guru, dan membaca buku paket untuk memperoleh ide dalam menyelesaikan soal LKS. Tidak jarang suasana pembelajaran sedikit lebih gaduh dari pada kelas kontrol.

Dari penjelasan tersebut, ditegaskan bahwa pembelajaran dengan model pembelajaran kooperatif tipe PBL lebih baik hasilnya dari pada hasil belajar dengan model pembelajaran konvensional. Suatu pembelajaran yang dapat memotivasi siswa untuk saling terpacu memahami materi yang telah disajikan oleh guru, sehingga siswa mampu membuat dan sekaligus dapat menjawab soal-soal.

\section{Aktifitas Belajar Siswa Dalam Pembelajaran Yang Diajar Dengan Menggunakan Model PBL (Kelas Eksperimen)}

Untuk mendapatkan data aktifitas belajar didasarkan pada pengamatan yang dilakukan oleh seorang guru yang berperan sebagai observer. Beberapa cara di atas yang dilakukan untuk menumbuhkan aktivitas belajar siswa. Tentunya, dalam hal ini guru menjadi pendorong bagi siswa dalam belajar. Guru mampu melaksanakan perannya terhadap siswa dalam belajar, membimbing, mengarahkan bahkan memberikan tes untuk mengukur seberapa besar kemampuan siswa dalam pembelajaran. Indikator yang menunjukkan adanya aktivitas belajar siswa disajikan pada tabel 7 .

Tabel 7. Hasil Pengamatan Indikator Aktifitas Belajar Siswa Kelas Eksperimen

\begin{tabular}{|c|c|c|c|c|}
\hline \multirow{2}{*}{ No } & \multirow{2}{*}{ Indikator } & \multicolumn{2}{|c|}{ Jumlah siswa aktif } & \multirow{2}{*}{ Total rata-rata } \\
\hline & & KD Gerak & KD S. Sirkulasi & \\
\hline 1 & Siswa membaca materi yang akan dipelajari. & 28 & 32 & 30 \\
\hline 2 & Siswa berdiskusi dengan teman & 15 & 23 & 26 \\
\hline 3 & Siswa bertanya pada guru atau teman. & 10 & 17 & 13 \\
\hline 4 & Siswa menyimak penjelasan dari guru & 30 & 32 & 31 \\
\hline 5 & Siswa membuat catatan tentang materi pelajaran. & 23 & 31 & 38 \\
\hline 6 & Siswa bersemangat dalam mengikuti pelajaran. & 22 & 29 & 25 \\
\hline
\end{tabular}

Dari tabel 7, terlihat bahwa terjadi peningkatan aktifitas siswa pada KD kedua di semua indicator aktifitas pembelajaran. Secara umum lebih dari 90\% siswa menyimak penjelasan dari guru terlihat dari banyaknya jumlah siswa yang terlibat aktif. Indikator terendah berada pada indicator bertanya pada guru yakni hanya sebanyak 10 orang pada KD 1 dan 17 orang pada KD 2. Namun secara umum capaian data diatas telah masuk kategori baik. Hasil pengamatan indicator aktifitas tersebut selanjutnya dikonsultasikan pada range skala aktifitas belajar. Tabel 8. akan menyajikan kategori aktifitas belajar pada KD 1 dan KD 2.

Tabel 8. Kategori Aktifitas Belajar Pada KD 1 dan KD 2 Kelas Eksperimen

\begin{tabular}{|c|c|c|c|c|c|}
\hline \multirow{2}{*}{ No } & \multirow{2}{*}{ Indikator } & \multicolumn{4}{|c|}{ Jumlah siswa aktif } \\
\hline & & KD Gerak & Kategori & KD S. Sirkulasi & Kategori \\
\hline 1 & $\begin{array}{l}\text { Siswa membaca materi yang akan } \\
\text { dipelajari. }\end{array}$ & 77,77 & Sangat tinggi & 88,88 & Sangat tinggi \\
\hline 2 & Siswa berdiskusi dengan teman & 41,66 & Rendah & 63,88 & Tinggi \\
\hline 3 & Siswa bertanya pada guru atau teman. & 27,77 & Rendah & 47,22 & Rendah \\
\hline 4 & Siswa menyimak penjelasan dari guru & 83,33 & Sangat tinggi & 88,88 & Sangat tinggi \\
\hline 5 & $\begin{array}{l}\text { Siswa membuat catatan tentang materi } \\
\text { pelajaran. }\end{array}$ & 63,88 & Tinggi & 86,11 & Sangat tinggi \\
\hline 6 & $\begin{array}{l}\text { Siswa bersemangat dalam mengikuti } \\
\text { pelajaran. }\end{array}$ & 61,11 & Tinggi & 80,55 & Sangat Tinggi \\
\hline
\end{tabular}

Dari Tabel 8, terlihat bahwa terdapat peningkatan skor dan kategori dari KD 1 ke KD 2 . Peningkatan skor terjadi pada semua indicator. Pada KD 1 terdapat 2 kategori indicator yang masuk kategori rendah yaitu indicator siswa berdiskusi dengan teman dan indicator siswa bertanya pada guru dan teman. Untuk Kategori tinggi terdapat 2 indikator yakni insikator siswa membuat catatan tentang materi pembelajaran dan indicator siswa bersemangat dalam mengikuti pelajaran. Sementara itu juga terdapat 2 indikator pada kategori sangat tinggi yaitu indicator siswa membaca materi pelajaran dan siswa menyimak penjelasan dari guru.

Pada KD 2 terjadi peningkatan aktifitas yakni terdapat 1 kategori rendah pada indicator siswa bertanya pada teman dan guru, 1 indikator kategori tinggi yaitu siswa berdiskusi dengan teman dan 4 indikator kategori sangat baik yaitu Siswa menyimak penjelasan dari guru, Siswa membuat catatan tentang materi pelajaran, Siswa bersemangat dalam mengikuti pelajaran dan kategori siswa membaca materi yang akan dipelajari. Gambar 4.3 akan menyajikan Grafik peningkatan capaian aktifitas belajar pada KD 1 ke KD 2. 


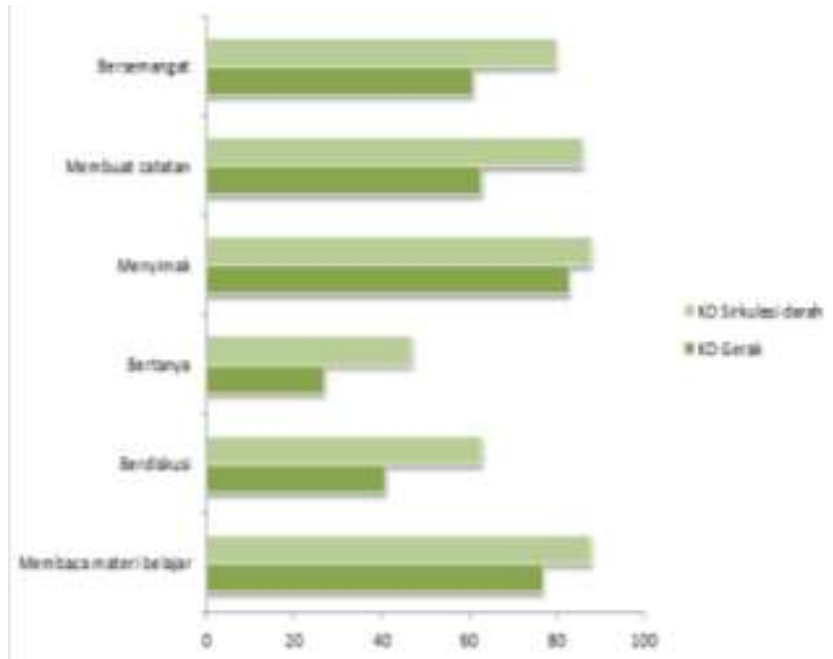

Gambar 3. indicator Aktiftas belajar KD 1 dan KD 2

Aktifitas Belajar Siswa Dalam Pembelajaran Yang Diajar dengan Menggunakan Model Konvensional Kelas Kontrol

Pembelajaran dengan menggunakan metode konvensioonal pada kleas kontrol juga diamati aktifitas belajar siswannya. Indikator Aktifitas belajar pada kelas Kontrol disajikan pada Tabel 9.

Tabel 9. Hasil Pengamatan Indikator Aktifitas Belajar Siswa Kelas Kontrol

\begin{tabular}{clccc}
\hline \multirow{2}{*}{ No } & \multicolumn{1}{c}{ Indikator } & \multicolumn{2}{c}{ Jumlah siswa aktif } & \multirow{2}{*}{ Total rata-rata } \\
\cline { 3 - 4 } 1 & Siswa membaca materi yang akan dipelajari. & KD Gerak & KD S. Sirkulasi & \\
\cline { 3 - 4 } 2 & Siswa berdiskusi dengan teman & 13 & 28 & 34 \\
3 & Siswa bertanya pada guru atau teman. & 12 & 17 & 15 \\
4 & Siswa menyimak penjelasan dari guru & 25 & 28 & 14 \\
5 & Siswa membuat catatan tentang materi pelajaran. & 20 & 30 & 26 \\
6 & Siswa bersemangat dalam mengikuti pelajaran. & 18 & 25 & 22 \\
\hline
\end{tabular}

Dari tabel 9, juga terlihat terjadi peningkatan aktifitas siswa pada KD kedua di semua indicator aktifitas pembelajaran. Secara umum lebih dari $80 \%$ siswa menyimak penjelasan dari guru terlihat dari jumlah siswa yang terlibat aktif. Indikator terendah berada pada indicator bertanya pada guru yakni hanya sebanyak 12 orang pada KD 1 dan 15 orang pada KD 2 . Jika dibandingkan dengan capaian aktifitas pada kelas eksperimen maka hasil aktifitas di kelas control sedikit lebih rendah. Namun secara umum capaian data di kelas kontrol telah masuk kategori baik. Hasil pengamatan indicator aktifitas tersebut selanjutnya dikonsultasikan pada range skala aktifitas belajar. Tabel 10 akan menyajikan kategori aktifitas belajar pada KD 1 dan KD 2 di kelas control.

Tabel 10. Kategori Aktifitas Belajar Pada KD 1 dan KD 2 Kelas Kontrol

\begin{tabular}{|c|c|c|c|c|c|}
\hline \multirow{2}{*}{ No } & \multirow{2}{*}{ Indikator } & \multicolumn{4}{|c|}{ Jumlah siswa aktif } \\
\hline & & KD Gerak & Kategori & KD Sirkulas & Kategori \\
\hline 1 & Siswa membaca materi yang akan dipelajari. & 55,55 & tinggi & 77,77 & Sangat tinggi \\
\hline 2 & Siswa berdiskusi dengan teman & 36,11 & Rendah & 47,22 & rendah \\
\hline 3 & Siswa bertanya pada guru atau teman. & 33,33 & Rendah & 41,66 & Rendah \\
\hline 4 & Siswa menyimak penjelasan dari guru & 69,44 & tinggi & 77,77 & Sangat tinggi \\
\hline 5 & $\begin{array}{l}\text { Siswa membuat catatan tentang materi } \\
\text { pelajaran. }\end{array}$ & 55,55 & Tinggi & 83,33 & Sangat tinggi \\
\hline 6 & Siswa bersemangat mengikuti pelajaran. & 50,00 & Rendah & 69,44 & tinggi \\
\hline
\end{tabular}

Dari Tabel 10, terlihat bahwa terdapat peningkatan skor dan kategori dari KD 1 ke KD 2 . Peningkatan skor terjadi pada semua indicator. Pada KD 1 terdapat 3 kategori indicator yang masuk kategori rendah yaitu indicator siswa berdiskusi dengan teman, Indikator siswa bersemangat dalam mengikuti pelajaran dan indicator siswa bertanya pada guru dan teman. Untuk Kategori tinggi terdapat 3 indikator yakni insikator siswa membuat catatan tentang materi pembelajaran dan indicator membaca materi pelajaran dan indicator siswa menyimak penjelasan dari guru. Sementara itu tidak terdapat kateori aktifitas belajar sangat tinggi dan sangat rendah. Pada KD 2 terjadi peningkatan aktifitas yakni terdapat 2 kategori rendah pada indicator siswa bertanya pada teman dan guru dan indicator siswa berdiskusi dengan teman. 1 indikator kategori tinggi yaitu siswa bersemangat dalam mengikuti pelajaran $\mathrm{d}$ an terdapat 3 indikator kategori sangat tinggi yaitu Siswa menyimak penjelasan dari guru, Siswa membuat catatan tentang materi pelajaran, Siswa dan kategori siswa 
membaca materi yang akan dipelajari. Gambar 4, akan menyajikan Grafik peningkatan capaian aktifitas belajar pada KD 1 ke KD 2.

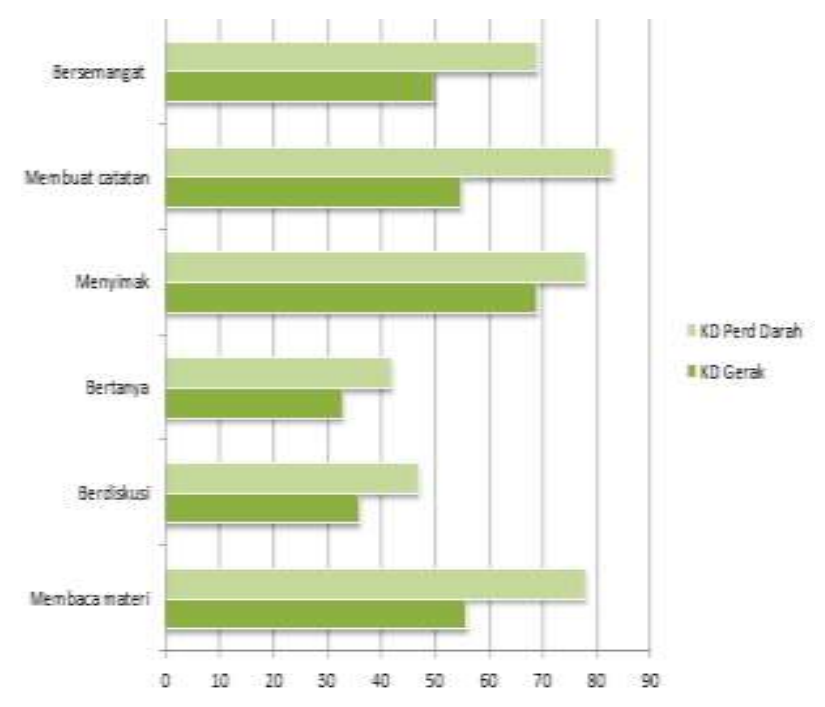

\section{Gambar 4. Indicator Aktiftas Belajar KD 1 dan KD 2 kelas Kontrol}

Dari hasil skor aktifitas belajar yang didapatkan secara umum harus aktifitas dikelas eksperimen lebih baik dibandingkan di kelas control hal tersebut dapat disebabkan oleh lebih terarahnya pembelajaran dengan model PBL yang memiliki sintak khusus. Siswa telah membaca materi, menyimak pertanyaan guru dan membuat catatan dengan baik. Meskipun begitu beberapa indicator aktifitas harus ditingkatkan seperti indicator bertanya dan keaktifan berdiskusi. Pembelajaran yang efektif adalah pembelajaran yang menyediakan kesempatan belajar sendiri atau melakukan aktivitas sendiri. Proses pembelajaran yang dilakukan di dalam kelas merupakan aktivitas mentransformasikan pengetahuan, sikap, dan ketrampilan (Martinis Yamin, 2007). Aktivitas merupakan prinsip atau asas yang sangat penting dalam interaksi belajar mengajar (Sardiman, 2006). Saat pembelajaran belangsung siswa mampu memberikan umpan balik terhadap guru. Sardiman (2006) menyatakan bahwa aktivitas belajar merupakan aktivitas yang bersifat fisik maupun mental. Dalam kegiatan belajar keduanya saling berkaitan. Oemar Hamalik (2009) menyatakan bahwa aktivitas belajar merupakan kegiatan yang dilakukan oleh siswa dalam kegiatan pembelajaran. Aktivitas belajar dapat terwujud apabila siswa terlibat belajar secara aktif. Martinis Yamin (2007: 82) mendefinisikan belajar aktif sebagai usaha manusia untuk membangun pengetahuan dalam dirinya. Pembelajaran akan menghasilkan suatu perubahan dan peningkatan kemampuan, pengetahuan dan ketrampilan pada diri siswa. Siswa mampu menggali kemampuannya dengan rasa ingin tahunya sehingga interaksi yang terjadi akan menjadi pengalaman dan keinginan untuk mengetahui sesuatu yang baru.

Berdasarkan pendapat diatas, dapat disimpulkan bahwa aktivitas belajar merupakan kegiatan atau tindakan baik fisik maupun mental yang dilakukan oleh individu untuk membangun pengetahuan dan ketrampilan dalam diri dalam kegiatan pembelajaran. Aktivitas belajar akan menjadikan pembelajaran yang efektif. Guru tidak hanya menyampaikan pengetahuan dan ketrampilan saja. Namun, guru harus mampu membawa siswa untuk aktif dalam belajar. Menurut Martinis Yamin (2007) terdapat beberapa hal yang dapat meningkatkan aktiiftas belajar diantaranya: 1). Memberikan topik atau permasalahan sebagai stimulus siswa untuk berpikir terkait dengan materi yang akan dipelajari. 2). Memberikan petunjuk kepada siswa cara mempelajarinya, 3) Memunculkan aktivitas dan partisipasi siswa dalam kegiatan pembelajaran. 4) Memberikan umpan balik (feed back). 5) Memantau pengetahuan siswa dengan memberikan tes. 6) Menyimpulkan setiap materi yang disampaikan di akhir pelajaran. Beberapa cara tersebut yang dilakukan untuk menumbuhkan aktivitas belajar siswa. Tentunya, dalam hal ini guru menjadi pendorong bagi siswa dalam belajar. Guru mampu melaksanakan perannya terhadap siswa dalam belajar, membimbing, mengarahkan bahkan memberikan tes untuk mengukur seberapa besar kemampuan siswa dalam pembelajaran. Sementara bagi siswa keuntunga yang didapat dari aktifitas belajar adalah 1) Siswa mencari pengalaman sendiri dan langsung mengalami sendiri dalam belajar. 2) Berbuat sendiri akan mengembangkan seluruh aspek pribadi siswa secara integral. 3) Memupuk kerja sama antar siswa sehingga siswa mampu bekerjasama dengan baik dan harmonis. 4) Siswa bekerja menurut minat dan kemampuan sendiri. Dan 5) Memupuk terciptanya disiplin kelas dan suasana belajar menjadi demokratis (Oemar hamalik, 2010)

\section{Uji Hipotesis Hasil Belajar}

Pengujian hipotesis penelitian dilakukan dengan teknik analisis uji $\mathrm{t}$ yaitu melihat pengaruh rerata hitung antara kelompok eksperimen (kooperatif PBL) dan kelompok kontrol (pembelajaran konvensional), dengan rata-rata (mean) 63,99 kelompok eksperimen dan rerata (mean) 67,03 kelompok kotrol dengan $t_{\text {hitung }} 2,304$ dan $t_{\text {tabel }} 1,687$ dan $\alpha 0,05 d k=44$. Data uji t hasil belajar disajikan pada Tabel 11. 
84 Instructional Development Journal (IDJ), Vol. 2, No. 2, Desember 2019, Hal. 76-85

Tabel 11. Rangkuman Hasil Pengujian Hipotesis Pertama

\begin{tabular}{lcccccc}
\hline Model Pembelajaran & Mean & $\mathbf{N}$ & thitung $_{\text {tat }}$ & $\boldsymbol{\alpha}$ & $\mathrm{L}_{\text {tabel }}$ & Keterangan \\
\hline Kooperatif PBL & 67,03 & 36 & 2,304 & 0,05 & 1,687 & Ha diterima \\
Konvesional & 63,99 & 36 & & & & \\
\hline
\end{tabular}

Berdasarkan Tabel 11, dapat dilihat bahwa thitung $(2,304)>t_{\text {tabel }}(1,687) \alpha 0,05 \mathrm{dan} \mathrm{dk}=44$, yang berarti tolak $\mathrm{H}_{0}$. Dapat disimpulkan hasil belajar siswa yang menggunakan model pembelajaran kooperatif PBL lebih tinggi dari pada siswa yang diajar dengan model konvensional.

\section{Uji Hipotesis Aktifitas Belajar}

Uji statistik aktifitas belajar siswa kelompok eksperimen dengan kelompok control. Kelompok yang diajar dengan menggunakan model pembelajaran konvensional, dengan rata-rata (mean) 67,58 kelompok eksperimen dan rerata (mean) 57,42 kelompok kotrol dengan $\mathrm{t}_{\text {hitung }}$ 1,839 dan $\mathrm{t}_{\text {tabel }} 1,721$ dan $\alpha$ 0,05 $\mathrm{dk}=21$, disajikan pada Tabel 12.

Tabel 12. Rangkuman Hasil Pengujian Hipotesis Kedua

\begin{tabular}{lcccccc}
\hline Model Pembelajaran & Mean & $\mathbf{N}$ & $\mathbf{t}_{\text {hitung }}$ & $\boldsymbol{\alpha}$ & $\mathrm{L}_{\text {tabel }}$ & Ket \\
\hline Kooperatif PBL & 67,58 & 36 & 1,829 & 0,05 & 1,721 & Ho ditolak \\
Konvesional & 57,42 & 36 & & & & \\
\hline
\end{tabular}

Dari kedua uji hipotesis baik terhadap hasil maupun aktifitas belajar didapatkan hasil bahwa terjadi perbedaan antara 2 pola pembelajaran tersebut. Pada pembelajaran yang tanpa menggunakan model pembelajaran PBL guru tidak memberikan kesempatan yang banyak kepada siswa untuk berinteraksi oleh guru. Hal ini menyebabkan siswa kurang bersemangat dalam mengikuti pembelajaran. Hasil penelitian ini sesuai dengan pendapat Rusman (2012) yakni model pembelajaran kooperatif dikembangkan guna mencapai hasil belajar kompetensi akademik. Model ini unggul dalam membantu siswa memahami konsep-konsep yang sulit. Siswa pada kelompok bawah maupun atas bekerjasama menyelesaikan tugas-tugas akademik, siswa kelompok atas menjadi tutor bagi siswa kelompok bawah. Selain itu untuk aktifitas juga lebih baik pada pembelajaran PBL. Menurut Hamalik (2009) bahwa aktivitas siswa selama proses pembelajaran merupakan salah satu indikator adanya keinginan siswa untuk belajar. Pembelajaran menitikberatkan pada aktivitas siswa dimana siswa belajar sambil bekerja. Dengan bekerja siswa memperoleh pengetahuan, pemahaman, dan keterampilan serta prilaku lainnya. Menurut Rusman (2011) keaktifan siswa dalam kegiatan pembelajaran sangat tergantung dari pemanfaatan potensi yang dimiliki oleh siswa itu sendiri. Keaktifan siswa dalam menjalani proses belajar mengajar merupakan salah satu kunci keberhasilan pencapaian tujuan pembelajaran. Hal ini sejalan dengan pendapat Sardiman (2014:97) dalam kegiatan belajar, siswa harus aktif berbuat, dengan kata lain bahwa dalam belajar sangat diperlukan adanya aktivitas. Tanpa aktivitas, proses belajar tidak mungkin berlangsung dengan baik.

\section{SIMPULAN DAN SARAN}

\section{Simpulan}

Hasil belajar siswa yang diajar dengan pembelajaran PBL sebesar 67, 03 lebih baik dibandingkan dengan hasil belajar siswa dengan pola konvensional yakni sebesar 63,99. Aktifitas belajar siswa yang diajar dengan pembelajaran PBL sebesar 67, 58 lebih baik dibandingkan dengan aktifitas belajar siswa dengan pola konvensional yakni sebesar 57,41. Model PBL memberikan hasil lebih baik dibandingkan Model Konvensional terhadap hasil belajar siswa. Terdapat perbedaan aktifitas belajar antara siswa yang diajarkan dengan pembelajaran model PBL dengan Model belajar Konvensional. Model PBL memberikan hasil lebih baik dibandingkan Model Konvensional terhadap aktifitas belajar siswa.

\section{Saran}

Pembelajaran kooperatif model PBL dapat digunakan pada kd materi yang lain. Pembelajaran kooperatif model PBL dapat dikombinasikan dengan model pembelajaran lain agar hasil yang didapatkan lebih maksimal.

\section{DAFTAR RUJUKAN}

Amir, Taufiq. 2010. Pendidikan Melalui Problem Based Learning. Jakarta: Kencana Prenada Media group.

Arikunto, Suharsimi; Suhardjono; Supardi. 2003. Penelitian Tindakan Kelas. Jakarta : Bumi Aksara

Chin Pei Tan a, , 1, H.T. Van der Molen b, H.G. Schmidt b. 2016. To what extent does problem-based learning contribute to students professional identity development? Teaching and Teacher Education. Journal Science Direct Teaching and Teacher Education. homepage: www.elsevier.com/locate/tate.

Dimyati dan Mujiono. 2002. Belajar dan Pembelajaran. Jakarta. Rineka Cipta

Elaine H.J.Yewa,n, KarenGohb. 2016. Problem-Based Learning:An Over view of its Process and Impact on Learning. Available online at www.sciencedirect.com Health ProfessionsEducation2(2016)75-79.

Hidayah. 2008. Media pembelajaran. Modul ringkas. Tidak diterbitkan 
Hendro Darmojo dan Jenny R. F. Kaligis. 1992. Pendidikan IPA II. Jakarta: Depdikbud, Dirjen Dikti Proyek Pembinaan Tenaga Kependidikan.

Hamalik Oemar. 2014. Kurikulum dan Pembelajaran. Penerbit Bumi Aksara. Jakarta.

Michael J. Duncan n, MikeSmith, KathrynCook. 2016. Implementing online problem based learning (PBL) in post graduates new to both online learning and PBL: An example from streng than conditioning. journal homepage: www.elsevier.com/locate/jhlste

Nana Sudjana. 2007. Penilaian Hasil Proses Belajar Mengajar. Bandung : Remaja Rosdakarya

Nana Syaodih Sukmadinata. 2007. Metode Penelitian Pendidikan. Jakarata : Remaja Rosdakarya

Purwanto Ngalim. 2007. Psikologi Pendidikan. PT. Remaja Rosdakarya Bandung.

Rusman. 2011. Model-Model Pembelajaran. Jakarta: Raja Grafindo Persada.

Samsiah Mata, Ruhizan Mohd.Yassinb, Noriah Ishakb, Nabishah Mohammadc, \& Santhna Letchumi Pandaragana. 2012. Model of problem-based learning using systems approach. Procedia - Social and Behavioral Sciences 60 doi: 10.1016/j.sbspro.2012.09.420. UKM

Sumiati \& Asra. 2007. Metode Pembelajaran. CV. Wacana Prima. Bandung

Sardiman. 2004. Interaksi dan motivasi belajar mengajar. Jakarta: Raja Grafindo Persada

Susilana rudi \&Cepi riyana. 2007. Media Pembelajaran. CV. Wacana Prima Bandung.

Tim pengembang MKDP. 2015. Kurikulum dan pembelajaran. UPI. Bandung

Tolga Erdogana, Nuray Senemoglub. 2014. Problem-Based Learning in Teacher Education: Its Promises andChallenges. Procedia - Social and Behavioral Sciences 116.

Ziad G. Nasr, Kyle John Wilby. 2016. Introducing problem-based learning into aCanadian-accredited Middle Eastern educational setting. Contents lists available at ScienceDirect Currents in Pharmacy Teaching and Learning journal homepage: www.elsevier.com/locate/cptl

Yamin, Martinis. 2007. Profesionalisasi Guru E Implementasi KTSP. Jakarta: Gaung Persada Press 